\title{
RATE EFFECT ON THE SHEAR RESISTANCE OF SANDY CLAY IN DIRECT SHEAR TESTS
}

\author{
Katarzyna Dołżyk-Szypcio ${ }^{\bowtie}$, Iwona Chmielewska \\ Faculty of Civil and Environmental Engineering, Bialystok University of Technology, Białystok
}

\begin{abstract}
The influence of shear velocity on shear resistance of a sandy clay at different moisture content and stress level during direct shear tests is investigated. The stress ratio and dilatancy relationship gives a new possibility of interpreting the results of direct shear tests results. The mobilized shear resistance is a function of pore pressure in a shear band and possibility of this pressure dissipation into the upper and lower part of the sample. The pore pressure in a shear band is an effect of volume changes and filtration of water from the shear band. Generally, at failure, the pore pressure in the shear band is a function of initial moisture, stress level and shear velocity. At failure, the pore pressure is negative for low moisture and low stress level, and positive for high moisture of soil and high stress level. Moisture level, stress level and shear velocity have significant influence on shear resistance of soil.
\end{abstract}

Key words: dilatancy, direct shear, rate of shearing

\section{INTRODUCTION}

The impact of strain rate on soil response is important in many areas of geotechnical engineering as they influence the strength and stiffness of soils. Examples of practical problems where the rate - dependency behaviour of soils is important are the following: stability of slopes, pale penetration, laboratory and site testing. The drainage effect is significant. At extremely slow rate there is time for pore pressure developed during shearing to dissipate fully. As the strain rate increases, the time for drainage reduces and the pore pressure increases and hence lower shear strength is observed in partially drained condition. As the strain rate goes up further, the conditions become almost fully undrained and viscous effect causes the shear strength increase up to a potential viscous limit (Brown \& Hyde, 2008; Lehane, O’Loughlin, Gaudin \& Randolph, 2009; Chow \& Airay, 2011; Quinn \& Brown, 2011; Briaud, 2013; Robinson \& Brown, 2013).

In saturated soils, contraction develops pore pressure whereas dilation reduces pore pressure during shear volumetric strain changes. The dilation can cause suction at some conditions of drainage and dilation rate. At critical and residual states (no dilation) the strength of soil remains rather unaffected by the rate of shearing under low to medium strain rate (Sorensen, Baudet \& Simpson, 2007; Diaz-Rodriguez, Martinez-Vasquez \& Santamarina, 2009; Bhat, Bhandary \& Yatabe, 2013). The effect of strain rate on effective strength parameters remains unclear. In general, it appears that higher strain rate leads to higher effective strength envelope (Diaz-Rodriguez et al., 2009). For direct shear tests a thin shear band (10-15) $D_{50}$ in the middle height of sample is sheared and volumetric strains occur. The rate of pore pressure changing in shear band caused by 
changes of volume is a function of initial porosity and moisture, stress level, permeability of soil and rate of shearing.

In this paper the results of direct shear tests of sandy clay at different moisture, stress level and strain rate are shown. During tests the vertical and horizontal forces and displacements were automatically collected. Beside shear stress and changes of sample height stress ratio and dilatancy relationships were analysed. Almost in all tests the point at which stress ratio significantly changes was observed. Therefore, the Frictional State Theory (Szypcio, 2016, 2017a, b) used for the analysis gave new possibilities of direct shear tests results interpretation.

\section{STRESS-DILATANCY FOR DIRECT SHEAR TESTS}

Treating the deformation of shear band in direct shear tests as simple shear (Szypcio, 2017b) and simple shear as a special case of plane strain shear (Szypcio, 2016) the stress-dilatancy equation obtained from the Frictional State Theory (Szypcio, 2016, 2017b) has a form

$$
\frac{\tau}{\sigma_{n}}=\frac{\sqrt{3} \eta \cos \phi^{\circ} \cos \theta}{3+\eta\left\{\sin \theta-\sqrt{3} \sin \phi^{\circ} \cos \theta\right\}}
$$

where

$$
\begin{gathered}
\eta=M_{b}^{o}-A_{b}^{o}\left(\alpha+\beta D^{p}\right) \\
M_{b}^{o}=\frac{3 \sin \phi^{\circ}}{\sqrt{3} \cos \theta-\sin \phi^{\circ} \sin \theta} \\
A_{b}^{o}=\frac{1}{\cos \left(\theta-\theta_{\varepsilon}\right)}\left\{1-\frac{2}{3} M_{b}^{o} \sin \left(\theta+\frac{2}{3} \pi\right)\right\} \\
D^{p}=D=-\sqrt{3} \frac{\delta h / \delta s}{\sqrt{1+4 / 3(\delta h / \delta s)^{2}}}
\end{gathered}
$$

where: $\varphi^{\circ}$ - angle of friction at critical frictional state; for many soils $\varphi^{\circ}=\varphi_{c v}$;

$\theta$ - Lode angle for stress; for simple shear it may be assumed that $\theta=15^{\circ}$;

$\theta_{\varepsilon}$ - Lode angle for strains increment; for direct (simple) shear.

$$
\theta_{\varepsilon}=\arctan \left(\frac{1}{\sqrt{3}} \frac{\delta h / \delta s}{\sqrt{1+(\delta h / \delta s)^{2}}}\right)
$$

where: $\delta h, \delta s-$ increments of vertical and horizontal displacement respectively ( $\delta h$ is positive for growth of sample thickness);

$\alpha, \beta-$ Frictional State Theory parameters.

\section{MATERIAL AND METHODS}

The tests were carried out on reconstituted sandy clay taken from weak subsoil from Bargłów area (Poland). The grading curve of tested sandy clay is shown in Figure 1 and basic physical properties are summarized in Table 1. 


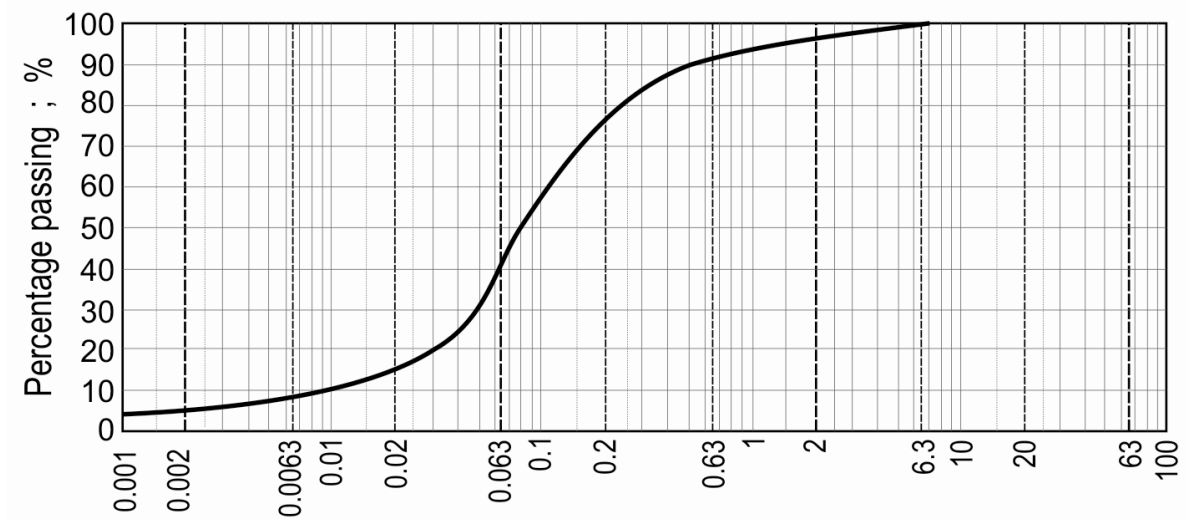

Particle size ; mm

Fig. 1. Grading curve of sandy clay

Table 1. Basic physical properties of sandy clay

\begin{tabular}{lll}
\hline Property & Unit & Value \\
\hline Density of solids, $\rho_{s}$ & $\mathrm{~g} \cdot \mathrm{cm}^{-3}$ & 2.71 \\
\hline Diameter of mean grain, $D_{50}$ & $\mathrm{~mm}$ & 0.08 \\
\hline Coefficient of uniformity, $C_{u}$ & - & 11.0 \\
\hline Coefficient of curvature, $C_{c}$ & - & 2.27 \\
\hline Natural moisture, $w$ & $\%$ & 16.05 \\
\hline Plastic limit, $w_{p}$ & $\%$ & 9.06 \\
\hline Liquid limit, $w_{L}$ & $\%$ & 22.32 \\
\hline Plasticity index, $I_{p}$ & $\%$ & 13.26 \\
\hline Clay fraction & $\%$ & 4.5 \\
\hline Activity & - & 2.95 \\
\hline
\end{tabular}

It is commonly accepted that critical friction angle of cohesive soils is a function of plasticity index. Basing on the given by Bond and Harris (2008) values $\varphi_{c v}$ for different values of $I_{p}$ the relationship between $\varphi_{c v}$ and $I_{p}$ was developed for $15 \% \leq I_{p} \leq 80 \%$ (Fig. 2). The extension of this relationship for $0 \% \leq I_{p}<15 \%$ give $\varphi_{c v}=31^{\circ}$ for the tested soil $\left(I_{p}=13.26 \%\right)$.

The samples for tests were prepared for moisture 8,12 and $16 \%$. These were then trimmed to $20 \mathrm{~mm}$ high and $63.5 \mathrm{~mm}$ diameter to create samples for shearing. The tests were carried out in an ordinary direct shear apparatus modified to automatically measure vertical and horizontal forces and displacements. The scheme of apparatus is shown in Figure 3.

At specified moisture three samples were tested at one of specified velocity displacement: $0.1,1.0$ and $10.0 \mathrm{~mm} \cdot \mathrm{min}^{-1}$, and specified vertical stress: 50,100 and $200 \mathrm{kPa}$. The sample installed in direct shear apparatus was vertically compressed to a specified value of normal stress and sheared without delay (without consolidation) at a specified value of displacement velocity. The automatic digital system collects forces and displacements within a time interval $10 \mathrm{~s}$ for $\mathrm{v}=10 \mathrm{~mm} \cdot \mathrm{min}^{-1}, 1 \mathrm{~s}$ for $\mathrm{v}=1.0 \mathrm{~mm} \cdot \mathrm{min}^{-1}$ and $0.1 \mathrm{~s}$ for $\mathrm{v}=10 \mathrm{~mm} \cdot \mathrm{min}^{-1}$ 


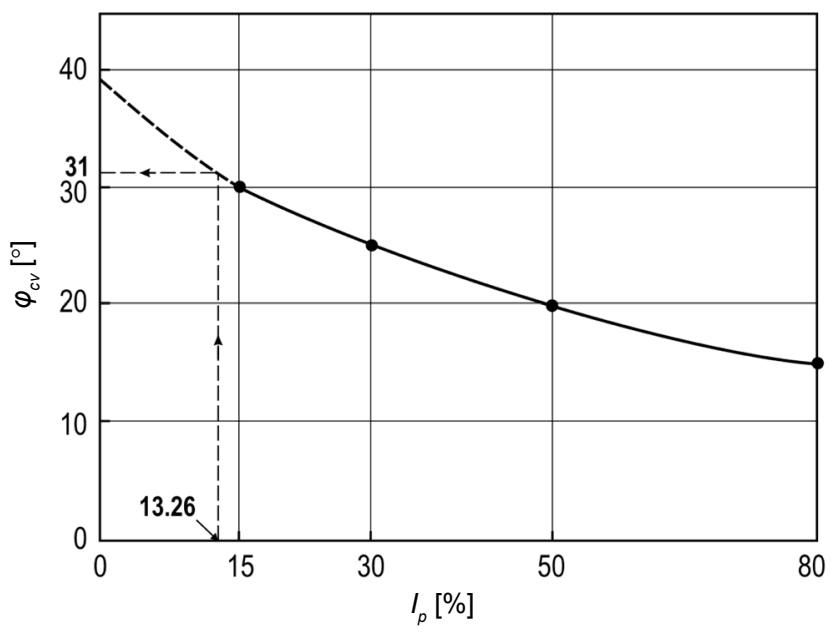

Fig. 2. Relationship $\varphi_{c v}-I_{p}$ for cohesive soils

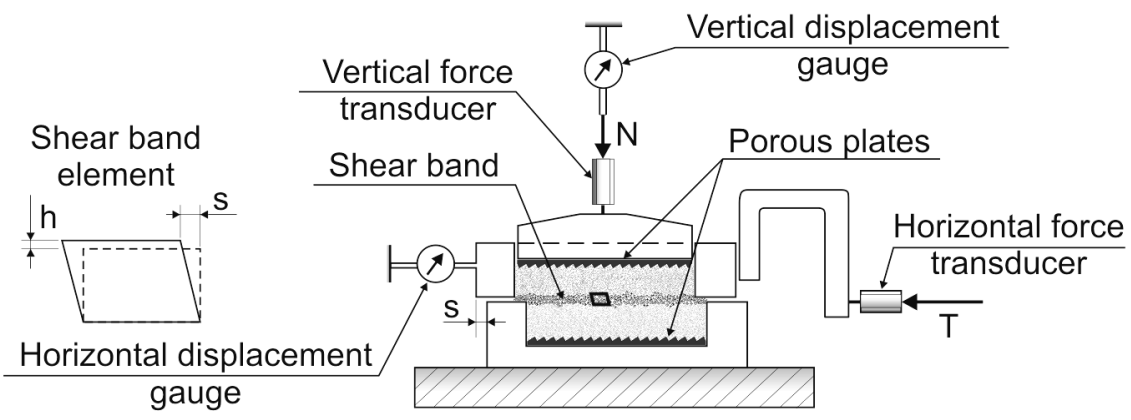

Fig. 3. Scheme of direct shear apparatus

and the data are recorded on the PC. The forces acting on the sample were measured with $1 \mathrm{~N}$ and displacement with $0.01 \mathrm{~mm}$ accuracy. All tests were interrupted at horizontal displacement $14-16 \mathrm{~mm}$.

\section{RESULTS}

For every test the relationships: $\tau-s, h-s$ and $\tau / \sigma_{n}-\delta h / \delta s$ were computed (Fig. 4). For almost all tests shapes of lines were similar. In Figure $4 \mathrm{c}$ the theoretical straight line obtained from Frictional State Theory (Szypcio, 2016) for $\varphi^{\circ}=31^{\circ}$ at initial stage of shearing is also shown. At initial stage of shearing a sample contracts, $(\delta h<0)$ and the stress ratio grows. It is observed for almost all tests that if dilatancy reaches the value of about $(-0.04)$ the increments of stress ratio $\left(\tau / \sigma_{n}\right)$ grow much more intensively than before. The point where this characteristic change was observed is marked as $T$-point in $\tau / \sigma_{n}-\delta h / \delta s$ plane (Fig. 4c) and named as transformation point. The value of dilatancy at this point is marked as $(\delta h / \delta s)^{*}$ and correspondent stress ratio $\left(\tau / \sigma_{n}\right)^{*}$. The transformation point $(T)$, corresponding shear stress $\left(\tau^{*}\right)$, contraction of sample $\left(h^{*}\right)$ and shear displacement $\left(s^{*}\right)$ are shown in Figures $4 \mathrm{a}$ and $4 \mathrm{~b}$. At advanced stage of shearing the increments of sample height become positive $(\delta h>0)$ and at some shear displacement, the shear stress and stress ratio reach the maximum values, $\tau_{\max },\left(\tau / \sigma_{n}\right)_{\max }$. For almost each test at advanced shearing the decrease of shear stress and stress ratio and small positive increment of sample height were observed. The mean characteristic values from three tests for specified moisture, normal stress and displacement velocity are summarized in Table 2 . 

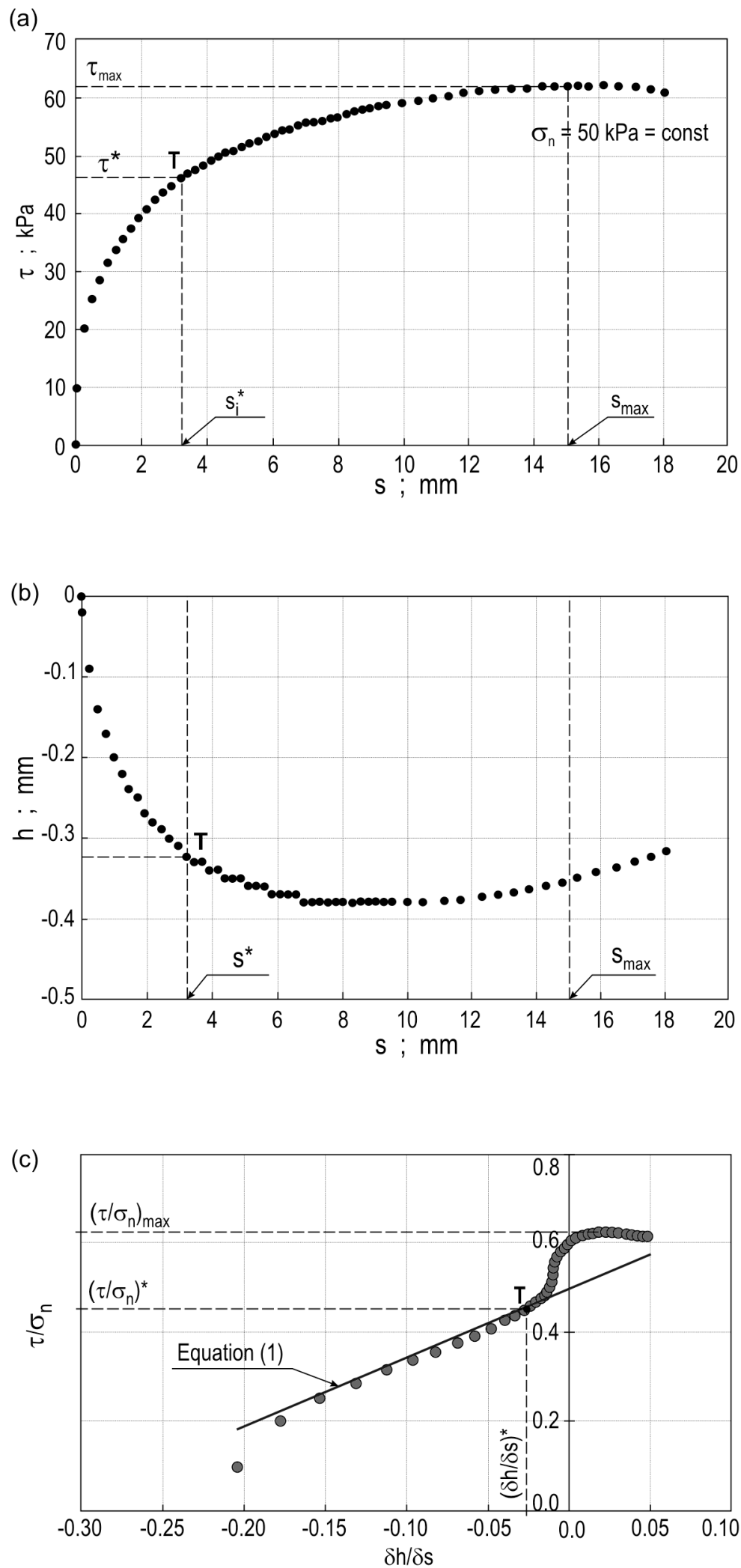

Fig. 4. Example of test results relationships: (a) $\tau-s$, (b) $h-s$, (c) $\tau / \sigma_{n}-\delta h / \delta s$ 
Dołżyk-Szypcio, K., Chmielewska, I. (2017). Rate effect on the shear resistance of sandy clay in direct shear tests. Acta Sci. Pol. Architectura, 16 (4), 15-25. doi: 10.22630/ASPA.2017.16.4.02.

Table 2. Characteristic points and values of tests results

\begin{tabular}{|c|c|c|c|c|c|c|c|c|c|c|c|c|}
\hline $\begin{array}{c}\sigma_{n} \\
{[\mathrm{kPa}]}\end{array}$ & $\begin{array}{c}\mathrm{v} \\
{\left[\mathrm{mm} \cdot \mathrm{min}^{-1}\right]}\end{array}$ & $\begin{array}{c}w \\
{[\%]}\end{array}$ & $\begin{array}{c}\alpha \\
{[-]}\end{array}$ & $\begin{array}{c}\beta \\
{[-]}\end{array}$ & $\begin{array}{c}(\delta h / \delta s)^{*} \\
{[-]}\end{array}$ & $\begin{array}{c}h^{*} \\
{[\mathrm{~mm}]}\end{array}$ & $\begin{array}{c}s^{*} \\
{[\mathrm{~mm}]}\end{array}$ & $\begin{array}{c}\left(\tau / \sigma_{n}\right)^{*} \\
{[-]}\end{array}$ & $\begin{array}{c}\tau^{*} \\
{[\mathrm{kPa}]}\end{array}$ & $\begin{array}{c}s_{\max } \\
{[\mathrm{mm}]}\end{array}$ & $\begin{array}{c}\left(\tau / \sigma_{n}\right)_{\max } \\
{[-]}\end{array}$ & $\begin{array}{c}\tau_{\max } \\
{[\mathrm{kPa}]}\end{array}$ \\
\hline \multirow{9}{*}{50} & \multirow{3}{*}{0.1} & 8 & -0.57 & 1.35 & -0.080 & -0.31 & 2.9 & 0.90 & 45.0 & 10.0 & 1.22 & 61.0 \\
\hline & & 12 & - & 1.32 & -0.050 & - & 2.8 & 0.73 & 36.5 & 6.0 & 0.98 & 49.0 \\
\hline & & 16 & 0.00 & 1.40 & -0.040 & -0.57 & 2.5 & 0.52 & 26.0 & 8.0 & 0.78 & 39.0 \\
\hline & \multirow{3}{*}{1.0} & 8 & -0.43 & 1.60 & -0.050 & -0.35 & 3.4 & 0.89 & 44.5 & 7.0 & 1.12 & 56.0 \\
\hline & & 12 & -0.10 & 1.45 & -0.030 & -0.34 & 3.2 & 0.64 & 32.0 & 8.0 & 0.76 & 38.0 \\
\hline & & 16 & 0.37 & 1.70 & -0.020 & -0.15 & - & 0.33 & 16.5 & 17.0 & 0.60 & 30.0 \\
\hline & \multirow{3}{*}{10.0} & 8 & -0.70 & 1.73 & 0.100 & -0.50 & 4.8 & 0.92 & 46.0 & 8.0 & 1.17 & 58.0 \\
\hline & & 12 & -0.53 & 2.20 & 0.040 & -0.47 & 4.5 & 0.41 & 22.0 & 6.0 & 0.62 & 31.0 \\
\hline & & 16 & -0.46 & - & -0.025 & -0.17 & 4.0 & 0.24 & 12.0 & 6.0 & 0.26 & 13.0 \\
\hline \multirow{9}{*}{100} & \multirow{3}{*}{0.1} & 8 & -0.43 & 1.45 & -0.055 & - & 2.8 & 0.675 & 67.5 & 9.0 & 1.00 & 100.0 \\
\hline & & 12 & -0.31 & 1.20 & -0.040 & -0.64 & 2.0 & 0.57 & 57.0 & 7.0 & 0.84 & 84.0 \\
\hline & & 16 & 0.05 & 1.15 & -0.035 & -0.60 & 2.5 & 0.50 & 50.0 & 9.0 & 0.72 & 72.0 \\
\hline & \multirow{3}{*}{1.0} & 8 & -0.43 & 1.40 & -0.070 & -0.87 & 4.0 & 0.76 & 76.0 & 9.0 & 1.01 & 101.0 \\
\hline & & 12 & 0.12 & 1.20 & -0.400 & -0.36 & 3.7 & 0.46 & 46.0 & 7.0 & 0.66 & 66.0 \\
\hline & & 16 & 0.58 & 1.45 & -0.035 & -0.44 & - & 0.25 & 25.0 & 15.0 & 0.42 & 42.0 \\
\hline & \multirow{3}{*}{10.0} & 8 & -0.51 & 2.10 & -0.070 & -0.71 & - & 0.765 & 76.5 & 10.0 & 1.03 & 103.0 \\
\hline & & 12 & - & - & -0.030 & -0.37 & 3.2 & 0.39 & 39.0 & 11.0 & 0.49 & 49.0 \\
\hline & & 16 & 0.74 & 1.60 & -0.020 & -0.33 & - & 0.16 & 16.0 & 13.0 & 0.19 & 19.0 \\
\hline \multirow{9}{*}{200} & \multirow{3}{*}{0.1} & 8 & -0.33 & 1.20 & -0.085 & -0.73 & 2.8 & 0.633 & 126.7 & 9.0 & 0.863 & 172.7 \\
\hline & & 12 & -0.05 & 1.35 & -0.050 & -0.64 & 2.6 & 0.57 & 114.0 & 8.0 & 0.81 & 162.0 \\
\hline & & 16 & 0.05 & 1.10 & -0.035 & -0.82 & 2.5 & 0.52 & 104.0 & 9.0 & 0.67 & 134.0 \\
\hline & \multirow{3}{*}{1.0} & 8 & -0.34 & 1.40 & -0.065 & -0.92 & 6.2 & 0.74 & 148.0 & 12.0 & 0.90 & 180.0 \\
\hline & & 12 & 0.12 & 1.80 & -0.050 & -0.39 & 4.1 & 0.47 & 94.0 & 13.0 & 0.63 & 126.0 \\
\hline & & 16 & 0.59 & 1.65 & -0.040 & -0.40 & 4.4 & 0.21 & 42.0 & 14.0 & 0.43 & 86.0 \\
\hline & \multirow{3}{*}{10.0} & 8 & -0.34 & 1.55 & -0.040 & -0.76 & 3.5 & 0.66 & 132.0 & 10.0 & 0.925 & 185.0 \\
\hline & & 12 & 0.27 & 1.30 & -0.032 & -0.30 & 3.2 & 0.41 & 82.0 & 9.0 & 0.49 & 98.0 \\
\hline & & 16 & 0.79 & 1.30 & -0.020 & -0.20 & 3.1 & 0.15 & 30.0 & 12.0 & 0.17 & 34.0 \\
\hline
\end{tabular}


The transformation point is a boarder point between initial and advanced shearing stage. So at initial stage $\delta h / \delta s<(\delta h / \delta s)^{*}$ and at advanced stage $\delta h / \delta s \geq(\delta h / \delta s)^{*}$. At initial stage shearing localized in shear band causes contraction of shear band (sample) and increase of pore pressure in it. The water displaces from shear band to upper and lower parts of sample where pore pressure is smaller. The value and change of pore pressure in shear band are functions of initial moisture, normal stress and velocity of shear displacement. At transformation point increase of pore pressure caused by contraction is fully balanced by decrease of pore pressure caused by filtration of water from shear band to upper and lower parts of sample. At the first phase of advanced stage $(\delta h / \delta s)^{*}<\delta h / \delta s<0$ the decrease of pore pressure due to filtration is higher than the increase of pore pressure due to contraction of shear band. At the second phase of advanced stage $(\delta h / \delta s>0)$ the decrease of pore pressure is a sum effect of filtration and dilation of shear band. So, there is observed an intensive increase of stress ratio at this phase of shearing in $\tau / \sigma_{n}-\delta h / \delta s$ plane (Fig. $4 \mathrm{c}$ ). At maximum value of stress ratio the pore pressure may reach a negative value. The direct shear apparatus does not give possibility of pore pressure measurement. It is proper to notice that transformation point, very characteristic in stress ratio - dilatancy plane (Fig. 4c) is simply not visible in conventionally used soil mechanics $\tau-s$ and $h-s$ planes, which are conventionally used in soil mechanics (Figs $4 \mathrm{a}$ and $4 \mathrm{~b}$ ). The mobilized shear resistances represented by $c^{*}, \varphi^{*}$ and $c, \varphi$ (Fig. 5) for transitional and failure points are shown in Figures 6 and 7 and summarized in Table 3.

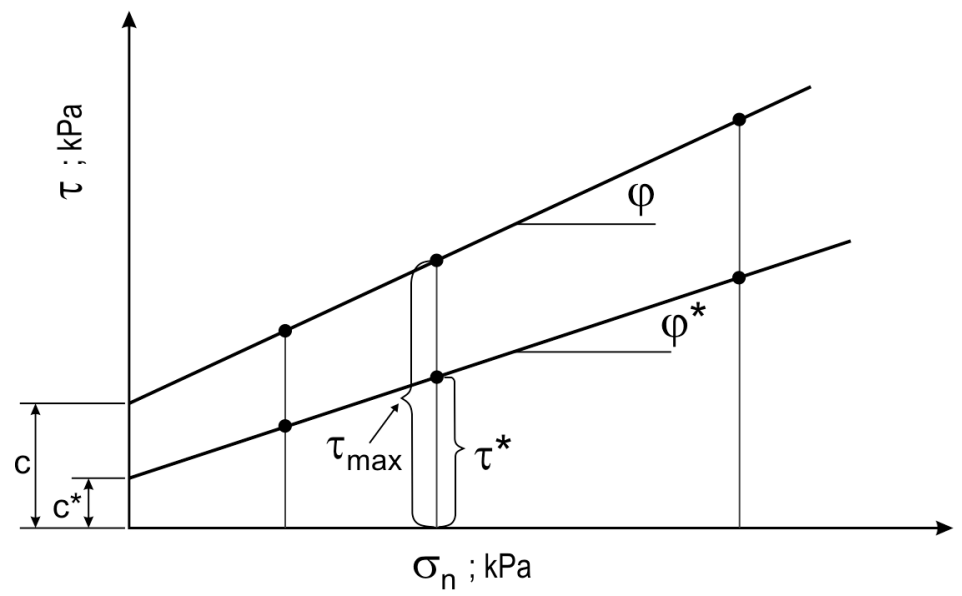

Fig. 5. Illustration of shear resistance parameters

It is noticeable that for soil moisture $w=8 \%$ the mobilized shear resistance is not significantly dependent on shear velocity. So, pore pressure does not significantly changes during shearing, probably due to not fully saturated soil at this moisture. The small bubbles of air in the soil are compressible and not very sensitive to the shear velocity. At failure, there are negative values of pore pressure, so values $c$ and $\varphi$ are a little higher than showed in literature for this soil (Wiłun, 2003).

For higher moisture, $w=12 \%$ and $w=16 \%$, soil is at plastic state, so it is saturated and values of pore pressure are very sensitive to volume change in shear band. The mobilized shear resistance significantly decreases with increase of shear velocity. The decrease of pore pressure due to filtration is much smaller than increase of pore pressure due to contraction of shear band (sample). The difference between the decrease and the increase is higher for higher shear velocity. 
Dołżyk-Szypcio, K., Chmielewska, I. (2017). Rate effect on the shear resistance of sandy clay in direct shear tests. Acta Sci. Pol. Architectura, 16 (4), 15-25. doi: 10.22630/ASPA.2017.16.4.02.

(a)

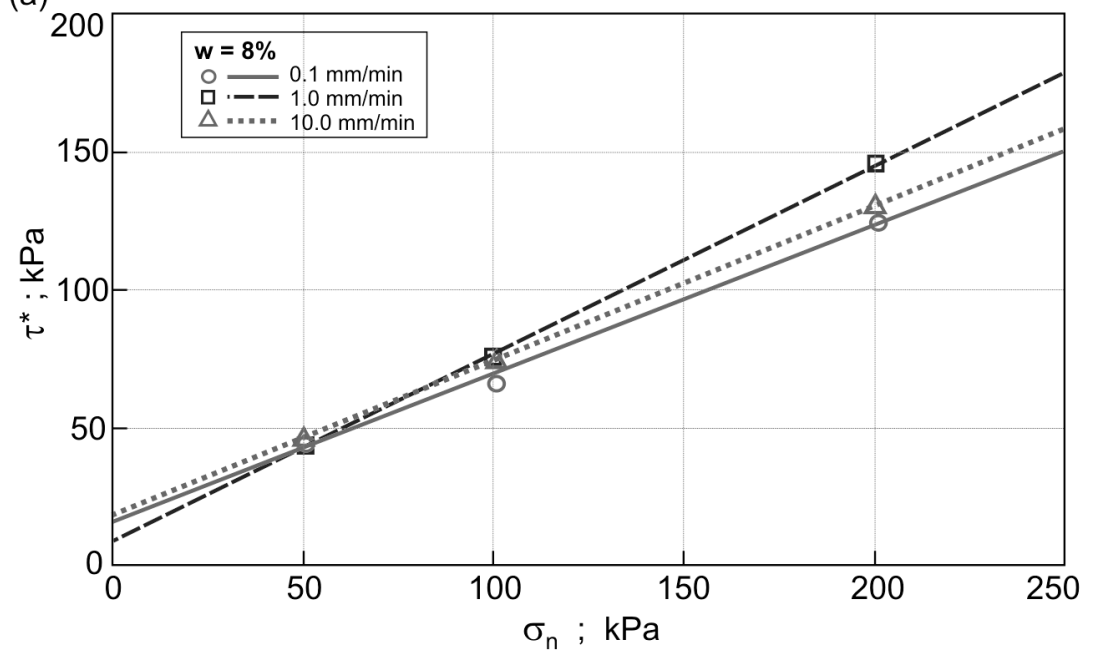

(b)

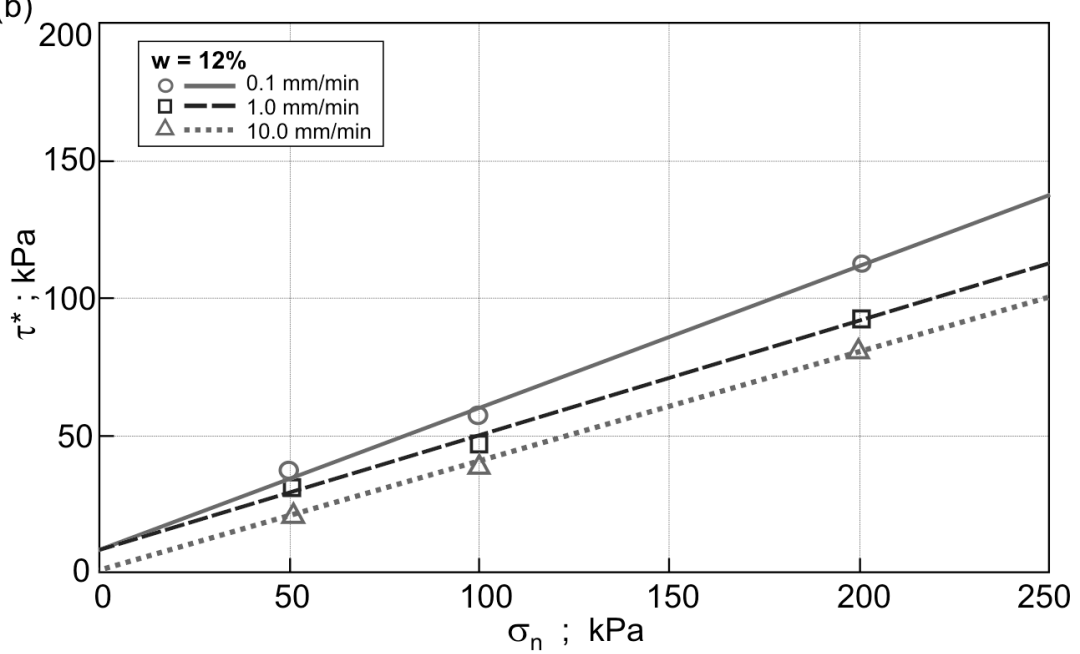

(c)

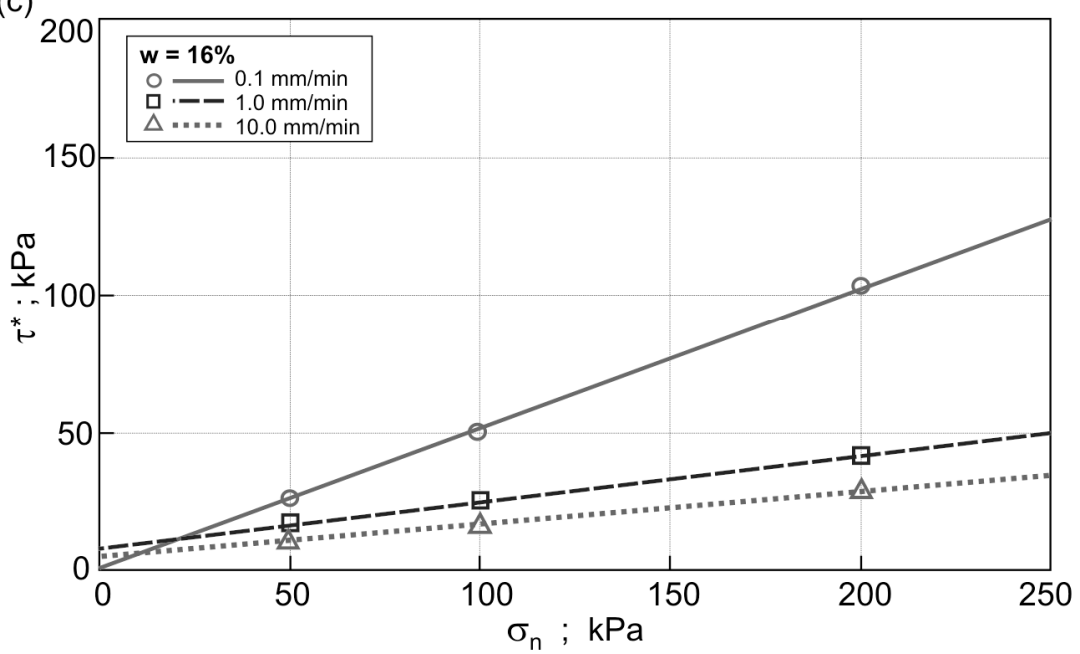

Fig. 6. Shear and normal stress relationship for transitional point: (a) $w=8 \%$, (b) $w=12 \%$, (c) $w=16 \%$ 
Dołżyk-Szypcio, K., Chmielewska, I. (2017). Rate effect on the shear resistance of sandy clay in direct shear tests. Acta Sci. Pol. Architectura, 16 (4), 15-25. doi: 10.22630/ASPA.2017.16.4.02.
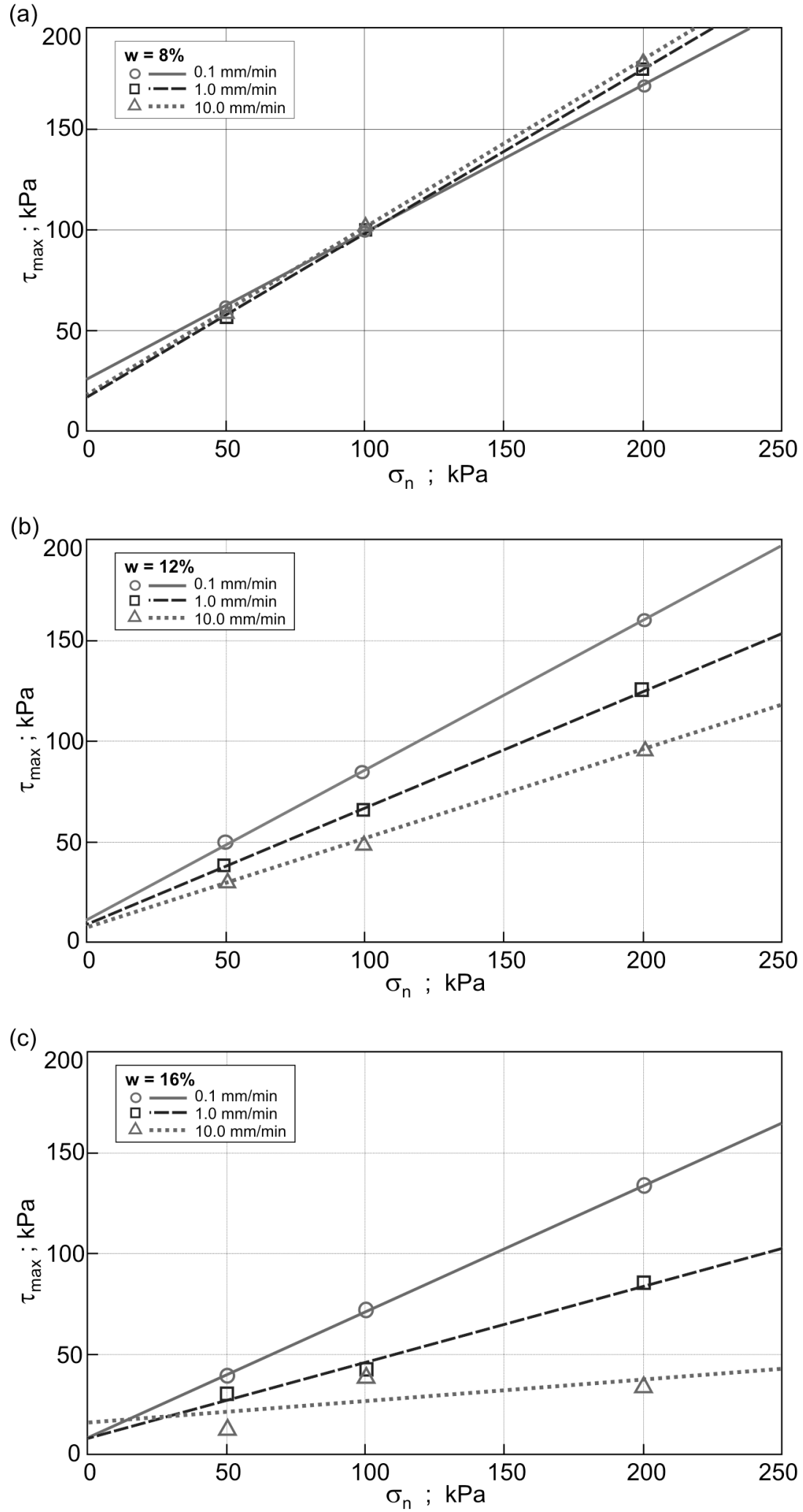

Fig. 7. Shear and normal stress relationship for failure point: (a) $w=8 \%$, (b) $w=12 \%$, (c) $w=16 \%$ 
Table 3. Strength parameters of soils

\begin{tabular}{cccccc}
\hline \multirow{2}{*}{$\begin{array}{c}w \\
{[\%]}\end{array}$} & $\begin{array}{c}\mathrm{v} \\
{\left[\mathrm{mm} \cdot \mathrm{min}^{-1}\right]}\end{array}$ & $\begin{array}{c}c^{*} \\
{[\mathrm{kPa}]}\end{array}$ & $\begin{array}{c}\Phi^{*} \\
{\left[{ }^{\circ}\right]}\end{array}$ & $\begin{array}{c}c \\
{[\mathrm{kPa}]}\end{array}$ & $\begin{array}{c}\Phi \\
{\left[{ }^{\circ}\right]}\end{array}$ \\
\hline \multirow{3}{*}{8} & 0.1 & 15.4 & 28.9 & 24.7 & 36.6 \\
\cline { 2 - 6 } & 1.0 & 8.5 & 34.7 & 16.5 & 38.5 \\
\hline \multirow{2}{*}{12} & 10.0 & 18.3 & 29.7 & 17.3 & 39.1 \\
\cline { 2 - 6 } & 0.1 & 8.0 & 27.7 & 10.0 & 35.1 \\
\hline \multirow{2}{*}{16} & 1.0 & 8.0 & 22.9 & 8.0 & 30.5 \\
\cline { 2 - 6 } & 10.0 & 1.5 & 22.0 & 6.5 & 24.4 \\
\hline & 1.0 & 1.0 & 27.6 & 8.0 & 32.3 \\
\hline
\end{tabular}

\section{CONCLUSIONS}

The shear velocity in direct shear tests significantly changes shear resistance of sandy clay. The changes are a function of initial moisture, stress level and shear velocity. The stress ratio and dilatancy relationship gives possibility to show the influence of volume changes in shear band on shear resistance. The pore pressure in shear band is summary effect of volume changes and filtration of water from shear band to upper and lower parts of sample. At the initial phase of shearing the shear band contracts and causes an increase of pore pressure. At transitional point the increase of pore pressure due to contraction is fully balanced by the decrease of pore pressure due to water filtration from shear band. At advanced shearing the increments of contraction are small and the increase of pore pressure due to contraction is smaller than decrease of pore pressure due to filtration. At advanced phase of shearing the decrease of pore pressure is the summary effect of influence of positive dilation and water filtration from shear band. Generally, at failure for moisture 12 and $16 \%$ the pore pressure is positive and shear resistance of soil is small. The shear resistance is smaller with a higher shear velocity. The influence of shear velocity on shear resistance should be regarded in relation to the results of laboratory and in situ tests' and some geotechnical works.

\section{Acknowledgement}

This work, carried out at Bialystok University of Technology, was supported by Polish financial resources on science under project S/WBiIS/6/2013.

\section{REFERENCES}

Bhat, D. R., Bhandary, N. P. \& Yatabe, R. (2013). Effect of Shearing Rate on Residual Strength of Kaolin Clay. The Electronic Journal of Geotechnical Engineering, 18, 1387-1395. Retrieved from http://www.ejge.com/2013/Ppr2013.122alr. pdf.

Bond, A. \& Harris, A. (2008). Decoding Eurocode 7. London and New York: Taylor \& Francis.

Briaud, J. L. (2013). Geotechnical Engineering. Unsaturated and Saturated soils. New Jersey: John Wiley \& Sons.

Brown, M. J. \& Hyde, A. F. L. (2008). Rate effects from pale shaft resistance measurements. Canadian Geotechnical Journal, 45 (3), 425-431. 
Chow, S. H. \& Airey, D. W. (2011). Rate effects in free falling penetrometer tests. Proceedings of the International Symposium on Deformation Characteristics of Geomaterials, Seoul, 592-599.

Diaz-Rodriguez, J. A., Martinez-Vasquez, J. J. \& Santamarina, J. C. (2009). Strain-rate effects in Mexico City soil. Journal of Geotechnical and Geoenvironmental Engineering, ASCE, 135 (2), 300-305.

Lehane, B. M., O'Loughlin, C. D., Gaudin, C. \& Randolph, M. F. (2009). Rate effect on penetrometer resistance in kaolin. Géotechnique, 59 (1), 41-52.

Quinn, T. A. C., \& Brown, M. J. (2011). Effect of strain rate on isotropically consolidated kaolin over a wide range of strain rates in triaxial apparatus. Proceedings of the International Symposium on Deformation Characteristics of Geomaterials, Seoul, 607-613.

Robinson, S. \& Brown, M. J. (2013). Rate effects at varying strain levels in fine grained soils. In Proceedings of the $18^{\text {th }}$ International Conference on Soil Mechanics and Geotechnical Engineering, Paris, 263-266.

Sorensen, K. K., Baudet, B. A. \& Simpson, B. (2007). Influence of Structure on the Time-Dependent Behaviour of a Stiff Sedimentary Clay. Géotechnique, 57 (1), 113-124.

Szypcio, Z. (2016). Stress-dilatancy for soils. Part I: The frictional state theory. Studia Geotechnica et Mechanica, 38 (4), $51-57$.

Szypcio, Z. (2017a). Stress-dilatancy for soils. Part III: Experimental validation for the biaxial conditions. Studia Geotechnica et Mechanica, 39 (1), 73-80.

Szypcio, Z. (2017b). Stress-dilatancy for soils. Part IV: Experimental validation for simple shear conditions. Studia Geotechnica et Mechanica, 39 (1), 82-88.

Wiłun, Z. (2003). Zarys geotechniki. Warszawa: Wydawnictwa Komunikacji i Łączności.

\section{WPŁYW PRĘDKOŚCI NA OPORY ŚCINANIA IŁÓW PIASZCZYSTYCH W BADANIACH BEZPOŚREDNIEGO ŚCINANIA}

\section{STRESZCZENIE}

W pracy badano wpływ prędkości ścinania na opór przy bezpośrednim ścinaniu glin piaszczystych (iłów piaszczystych, saCl) o różnej wilgotności przy różnych obciążeniach. Analiza zależności mobilizowanego oporu ścinania od zmian objętościowych (dylatancji) próbki daje nowe możliwości interpretacji wyników badań. Mobilizowany opór ścinania jest w znacznym stopniu funkcją ciśnienia wody w porach gruntu w strefie ścinania i możliwości rozpraszania tego ciśnienia do górnej i dolnej części próbki. Ciśnienie wody w porach gruntu jest funkcją początkowej wilgotności, poziomu obciążenia i prędkości ścinania. Przy zniszczeniu próbki wartość ciśnienia wody w porach gruntu może być dodatnia i znacznie obniżać wytrzymałość gruntu.

Słowa kluczowe: dylatancja, bezpośrednie ścinanie, prędkość ścinania 